Малинаускас Миндаугас Ромуальдович

интерн

Литовский университет здоровья

г. Каунас, Литовская Республика

DOI $10.21661 / r-116855$

\title{
EVALUATION OF ANXIETY AND DEPRESSION IN CARDIAC PATIENTS AFTER MYOCARDIAL INFARCTION
}

Аннотация: целью исследования является оценивание уровней тревоги и депрессии у больных с заболеванием сердиа, перенесенных инфаркт миокарда. Для достижения данной цели были использованы опросник депрессии Бэка и школа тревоги Бека. Результаты показали, что уровни тревоги и депрессии у женщин, перенесенных инфаркт миокарда, были выще, чем у мужчин с таким же заболеванием.

Ключевые слова: тревога, депрессия, больные с заболеванием сердиа, инфаркт миокарда.

Abstract: the purpose of the study is to evaluate anxiety and depression levels in cardiac patients after myocardial infarction. To achieve this goal the Beck's Depression Inventory and Beck's Anxiety Inventory were used in this study. The results showed that the levels of anxiety and depression were higher in women with myocardial infarction compared with men who had a myocardial infarction.

Keywords: anxiety, depression, cardiac patients, myocardial infarction.

Myocardial infarction is a serious and potentially life-threatening disease and represents a significant burden on the health-care system and society. Depression and anxiety are common disorders after myocardial infarction, which occur for about $65 \%$ of the patients who suffered from myocardial infarction and have an influence on $18 \%$ of the patients' life quality [1]. Depression and anxiety are the main reasons why these patients have a negative quality of life. People who suffer from depression have a six times higher death risk after six months of myocardial infarction [2]. Patients with depression and anxiety have been reported to have a higher rate of coronary interventions. 
Even though depression after myocardial infarction is common, this condition is rarely recognised [3]. Depression and anxiety in patients after myocardial infarction leads to poor medication adherence and may indirectly alter negative outcome.

There is a lack of studies in gender differences of anxiety and depression among cardiac patients after myocardial infarction. Therefore, this leads to a problem question: what are the levels of anxiety and depression in cardiac patients after myocardial infarction?

Methods. The second edition of Beck Depression Inventory-II [4] was used to evaluate depressive symptoms. This inventory included 21 multiple-choice questions that self-report the severity of depression symptoms. In this questionnaire each answer has a score on a scale value of $0-3$. The cut off points for different categories were as follows: minimal depression 0-13, mild depression 14-19, moderate depression 2028 and severe depression 29-63. The Beck Anxiety Inventory (BAI) [5], also a 21-item self-report multiple-choice questionnaire, was used to assess the severity of symptoms related to anxiety. Similar to BDI-II, each answer in BAI had a score on a scale value of $0-3$. The range of total scores was from 0 to 63 . The cut off points for classification are as follows: 0-7 minimal anxiety, $8-15$ mild anxiety, $16-25$ moderate anxiety, and 26-63 severe anxiety.

We selected 73 patients with myocardial infarction in our sample. The average age of men -52.6 years and of women -61.7 years. Forty-seven male and twenty-six female patients with myocardial infarction took part in the survey. Myocardial infarction diagnosis was based on WHO criteria.

Results. Use of Student's t-test revealed that statistically significant differences were found between the two study groups in levels of anxiety: females after myocardial infarction reported higher levels of anxiety than males after myocardial infarction (Table 1). However, evaluations of female and male patients statistically did not differ with respect to depression $(\mathrm{t}(71)=1,81 ; \mathrm{p}>0,05)$. 
Statistical indicators of anxiety and depression in cardiac patients

after myocardial infarction $(M \pm S D)$

\begin{tabular}{|c|c|c|c|c|}
\hline Indicator & Gender & $\mathrm{M} \pm \mathrm{SD}$ & $\mathrm{t}$ & $\mathrm{p}$ \\
\hline \multirow{2}{*}{ Anxiety } & Males & $08,81 \pm 5,43$ & \multirow{2}{*}{$-1,98$} & $\mathrm{p}<0,05$ \\
\cline { 2 - 3 } & Females & $11,59 \pm 5,89$ & & \multirow{2}{*}{$-1,81$} \\
\hline \multirow{2}{*}{ Depression } & Males & $09,11 \pm 6,72$ & $\mathrm{p}>0,05$ \\
\cline { 2 - 3 } & Females & $11,96 \pm 6,17$ & & \\
\hline
\end{tabular}

Discussion. It should be noted that some researchers [6] found significant differences in anxiety and depression of cardiac patients after myocardial infarction according to gender. The results of the present study revealed that females reported higher concern than males regarding the symptoms and beliefs of anxiety.

Depression is the most common mental illness in women and occurs twice as often than in men. The higher occurrence of depression and anxiety in women, combined with studies suggesting that women may have worse post- myocardial infarction prognosis than men, has led to the hypothesis that gender differences may be responsible for some differences in prognosis [6].

Conclusions. Statistical analysis showed that females after myocardial infarction reported higher levels of anxiety compared with males who have had a myocardial infarction. However, there were no gender differences in depression between males and females after myocardial infarction.

\section{References}

1. Guck T.P., Kavan M.G., Elsasser G.N., Barone E.J. Assessment and treatment of depression following myocardial infarction // American Family Physician. - 2001. No. 64 (4). - P. 641-648.

2. Frasure-Smith N., Lesperance F., Talajic M. Depression following myocardial infarction. Impact on 6-month survival // Journal of the American Medical Association. 1993, No. 270. - P. 1819 -1825.

3. Lauzon C., Beck C.A, Huynh T. et al. Depression and prognosis following hospital admission because of acute myocardial infarction // Canadian Medical Association Journal. - 2003. - No. 168. - P. 547-552. 
4. Beck A.T., Epstein N, Brown G. Steer R.A. An inventory for measuring clinical anxiety: psychometric properties // Journal of Consulting and Clinical Psychology. - 1988. - No. 56. - P. 893-897.

5. Beck A.T., Steer R.A., Ball R., Ranieri W. Comparison of Beck Depression Inventories-IA and -II in psychiatric outpatients // Journal of Personality Assessment. 1996. - No. 67. - P. 588-597.

6. Stewart W.F., Ricci J., Chee E., Hahn S.R., Morganstein, D. Cost of lost productive work time among US workers with depression // Journal of the American Medical Association. - 2003. - No. 289. - P. 3135-3144. 